\title{
DISCUSSIONS
}

\section{Historical and Cultural Experience: Intellectual Wealth of the Baltic Countries}

Plenary speech at the $25^{\text {th }}$ International Baltic Conference on the History of Science, Vilnius, 4-6 October 2012

The dates of several recent anniversaries inspired organizers of the $25^{\text {th }}$ International Baltic Conference on the History of Science (Historiae scientiarum Baltica 2012) to relate them to the plenary program, and, thus, to the content of this presentation. First and foremost, a fact relevant for the Baltic countriesthe 150-year anniversary of Riga Technical University - should be mentioned. Another relevant fact is connected with the University of Kaunas, which 90 years ago not only marked the establishment of a modern university, but also became a creative center of a twentieth-century national system of higher education. A third important event of 2012 was the $200^{\text {th }}$ anniversary of the first public museum in Lithuania (an open-air museum accessible to the general public). This is not just an incidental fact: exclusive and closed museums emerge together with the maturing of academic activities which present the demand for teaching and education.

While discussing the experiences of academic activities, one should remember another important fact: the University of Vilnius, established in 1579, became an international institution founded by the Jesuit Order, which was expanding throughout the world. The academic disciplines were taught in the universal language of Latin, while the faculty and the student body came from different countries. Here collided several Christian traditions: Catholic, Protestant, Greek Orthodox and Unitarian. Adepts of these traditions in Vilnius aimed to spread their faith as widely as possible by printing books and establishing schools. In this competitive cultural arena, which became a creative polylogue, there was also present a considerable Jewish population and some Islamic communities, composed of Jewish emigrants from the West, Karaites from Asia, and Tatars.

The Lithuanian University established in Kaunas became the $20^{\text {th }}$ century's development center of intellectual resources for the re-established nation state. Individuals, matured in this and other institutions established later, created an intellectual foundation upon which formed the cultural depository for the new modern state. Without the active participation of this institutional endeavor 
during the Second World War and the turbulence of violent events after that, it would have been impossible to preserve the national values. The experience drawn from an institutional system of higher education and science in the prewar period (the third and fourth decades) became not only an essential factor in cultural resistance, but also a valuable element of national survival during the war years and thereafter (Krikštopaitis, 1997, pp. 129-131). While discussing such a problematic issue it is useful to remember a comment by a Swedish scientist:

The $19^{\text {th }}$ and $20^{\text {th }}$ centuries are the period of immensely increased possibilities for communication and travel across boundaries and between continents. One outcome of the new possibilities has been a transnationalization of science, learning and higher education. However, this is also the period when science and universities have become, to an extent never experienced before, instruments in the service of nation states during peace and war. We can indeed speak of nationalization of the sciences and of universities. (Sörlin, 1996, p. 31)

The above raises a question: "Will the accumulation of national values suffice for us to achieve an honorable survival of the storms of European integration?" This question, as current events indicate, is pertinent and important. However, an even more important question emerges: "Maybe we already have conceded to abandon one very significant peculiarity-self-authenticity; maybe this characteristic prevents us from 'immersion' into the 'pleasures' of Euro-integration?” I think that these questions should be considered by science-by historians who possess in-depth knowledge flowing from historical researches. This leaves us with an obligation not only to forecast, but also to prepare a strategy of common action. Understandably, at today's conference, we do not have enough research results that would enable us to allocate a separate discussion session for this topic.

Mother tongue, as a vital national value, is for us a specific point in the discussion of European integration. Language is an artefact of both expression and content. This two-sided nature of language with its expression of both thought and action is a nation's accumulation of its experience and history and it reflects the social and psychological features of its users. This is how the Danish scholar Louis Hjelmslev has characterized language and it allows us to cast a new glance at (a) the role of national language in a resistive behavior mode and (b) the development of the phenomenon of double-faced double-dealing as part of resistance against coercion, and the danger of this behaviour once we are back in a society that is an independent state. This view is based on the assertion that society's way of life creates verbal and non-verbal texts interacting during any discussion. This 
idea is a natural outcome of Hjelmslev's (1975) suggestion to consider languages as structures that generate and transmit content. Let us try to discuss the above two claims.

It is a fact that in the Baltic States, mother tongue, by being actively used in daily life and activities, schools, universities, government agencies and elsewhere, did not permit the occupation regime's language to predominate. National language was the language of literature, science, pedagogy, journalism, and it was the basic form of expression and content handling. It withstood aggressive Soviet ideological pressures and the requirement to learn and use the Russian language in all official business. Despite attempts to impose Russian, the national Baltic languages continued to function. True, in several towns in Latvia and Estonia, there was strong Russian military presence due to the deployment of the Soviet War Fleet or other command posts. In such towns, Russian became the dominant language. Everywhere else, the basic ethnic culture was preserved, and although slowly, there was development in all areas of culture. National language, tradition, and non-verbal texts, such as national historical monuments and symbols, united two different parts of the society: those born in the country and those who had left it, the major part of the latter as war refugees. Common language rallied these different parts towards a joint goal of liberation. In that common language, content and expression complemented each other and stimulated resistive behaviour patterns, often double-faced because addressed to different audiences-one for "them", the repressive structures, and one for "us", the people. The mutual stimulus interaction worked by the passing illegal publications from hand to hand, listening to overseas radio broadcasts in the native language, influencing diplomats overseas. This cultural interaction allows us to claim today that national society, even if its fragments live apart on different continents, can create a united cultural discourse if both parts of the society synchronously experience the political, cultural and economic events of the native land.

The second point is that the occupying powers bring with them discourses of another culture and foreign ideology. In Lithuania, a self-defence reaction produces in the local population a way of speaking that is pointed at two different addressees determined autonomously—foreign versus ours. Two autonomous levels of association appear, each characterized with a specific vocabulary and diction. Each side evaluates the other and appropriately reacts to various signs during the interaction: accent, intonation, context, use of foreign words, and other characteristics. After a reciprocal evaluation a dual speech begins to flow 
in a society and its appropriate behaviour begins to draw a conditional line between 'foreign' and 'own', between those who collaborate and those who resist, between those that the community trusts and those who have lost the trust of the community. This line of demarcation is not strict but diffuse and convoluted.

The coexistence of these two different forms of speech and behaviour and their permanent hidden confrontational interaction developed the experience that we can characterize as the ability of society to act under conditions in the absence of freedom. This means that members of such a society have acquired enough skills to adapt themselves to the coercion exercised by the totalitarian authority. This adaptation fostered blocking of and opposition to everything that is forced from the outside. On the other hand, the same skill to survive oppression fostered confidence in one's own culture, nation, and native language expressions and accumulated experience.

Based on the new values of the $21^{\text {st }}$ century, the questions that I have raised may look like overhanging sentimental residual sprouts. However, historians' duty and research ethics demand that questions of importance for the national culture are raised, thus demanding an examination without delay. Unfortunately, we are currently drawn into vortexes of political, economic and social changes which hinder our concentration for essential work. Each step taken is accompanied with a question "Will we succeed in getting the funds for our sought-after goals?" Therefore, we often divert to temporary but useful one-day dead-end activities.

It is very dangerous to succumb to alluring slogans like "The all-powerful market forces will take care of everything". This phrase likes to declare the liberal extremists of the post-Soviet era. I think that a conscientious and competent scientist will dare to answer: "No, the market cannot solve everything, it is not omnipotent". Furthermore, concentrated prominence of the liberal phrase "the market will take care of everything" invokes tendencies destructive to the fundamentals of civilization. They are split up by the hypertrophied technology and consequences emerging from it.

The problem is that the market factor is helpless in stimulating fundamental sectors of culture and science which are needed for the goals of an independent and identity-fostering state. Other entrenched detriments are the frequent changes of governments in the Baltic States because each change initiates new political and tactical government decisions, thus derailing intellectual activities which are detrimental to the work going on at the universities. We witness that every day. 
The world's dominant civilization increasingly challenges academic research demanding obedience to it- "science must offer concrete innovations". By accepting such challenges two things remain undetermined: (1) how to achieve science's mission to national culture, and (2) how to achieve radically meaningful innovations? How can these be reconciled? I find that impossible. It is impossible because of two essential factors.

The first factor is as follows: the mission of science dedicated to national culture demands work which is not commercially useful. A matter of course, for it is impossible to find financial support for such work from the business sector (private sponsorship is still underdeveloped here and, in reality, it does not exist). What remains is state support which requires engagement with the state's cultural strategy. Unfortunately, that is not useful to political "games" and economic goals. Therefore, we have no real strategy-our goals are only temporary. If government leaders were able and willing to consider a look into the future, they would perceive that culture, as a value of civilization, is an essential investment in all aspects of its meaning.

The thesis defining the second factor asserts: "The mission of science to seek fundamental results demands a great amount of time resources and large investments. Without them no essential and radical discoveries can be achieved". Unfortunately, the Baltic countries have wasted their time and material resources, and expectations of great investments are not realistic.

Obviously we have a dilemma-how to match the unmatchable? If it is important for us not to lose our national values and originality, we must decide to increase the financing of culture as an investment. Such partial reconciliation of opposites, redistributing the weights of priorities, demands a clear policy on cultural strategy, thus reaching agreement among all the parameters of state's strategy. Unfortunately, no Baltic state has a clear and stable strategy. It changes with changes of governments. This means that the problem of national survival is a cumbersome problem. The real danger is our lack of determination to solve our essential problems.

I would not like to finish my consideration with the sad conclusion mentioned above. Therefore, I will only comment upon it by raising the question: "Maybe it would be worthwhile to talk about what unites us, about the common characteristics of the Baltic States, highlighting what is applicable to all the three nations?" Perhaps a concrete understanding of our affinity, of our alliance, would assist us in resolving such questions? Therefore, I will attempt to reflect 
on that from the aspects of the history of science and the experience of academic activities. ${ }^{1}$

To delineate such a community of thoughts and feelings, we should choose a way of mutual communication. If it would become possible to establish not episodic but continuous discussions and concrete consultations between the Baltic universities and subordinate organizations (faculties, departments), then new impulses might arise to compete for quality results from academic activity, which would stimulate a natural renewal. In addition, such participative approach to mutual communication would allow clearer outlines of educational and developmental features to emerge. Maybe this would allow the emergence of something that could be called a common Baltic regional identity. I think that such a scenario of intercommunications would be realistic, if we assessed the real dangers emerging from universally integrated culture and modus vivendi across the board. Regional identity and its embodiment into the consciousness of public leaders would create motivation for purposeful behavior which could act as a "barrier" against the dissolution of national cultures and their identities within the integration "kettle" of the European Union.

For us, members of the academic community in the Baltic States, it is important to foster and develop individuals capable of representing not only local (national) culture, but also to represent the regional Baltic and European culture and even that of the global civilization. It is clear that persons of broad erudition would be capable of creating cultural identities on four levels: national, regional, European and global. I emphasize - it is important for us that autonomous representation of different identities on indicated levels would be able to resist the homogenizing cultural pluralism.

\section{References}

Hjemslev, L. (1975), Résumé of a Theory of Language, København: Munksgaard/ Rosinante.

Krikštopaitis, J. A. (1996), 'Intellectual Activity and National Independence: Four Themes from the History of the Baltic States,' in University and Nation: The University and the Making of the Nation in Northern Europe in the $19^{\text {th }}$ and the $20^{\text {th }}$ centuries, Studia Historica, 53, Helsinki: Suomen Historiallinen Seura, pp. 65-75.

$1 \quad$ This proposition was disputed partially in Krikstopaitis, 1996, pp. 65-75. 
(1997), 'Baltic science in the $20^{\text {th }}$ century from the standpoint of social anthropology,' in B. Hoffmann, B. Severyns \& R. G. Stokes (eds.) Science, Technology and Political Change: Proceedings of the 20 $0^{\text {th }}$ International Congress of History of Science (Liège, 20-26 July 1997), Liège: Brepols, vol. 1, pp. 129-134.

Siilivask, K.; Krikštopaitis, J. A. \& Stradiňš, J. (1996), 'One the road to the intellectual entente of Baltic scientists,' [in Latvian] in Täds bija mùsu laiks..., Rīga: Sprīdītis, pp. $465-478$.

Sörlin, S. (1996), 'Science and national mobilization in Sweden,' in University and Nation: The University and the Making of the Nation in Northern Europe in the $19^{\text {th }}$ and the 20 $0^{\text {th }}$ centuries, Studia Historica 53, Helsinki: Suomen Historiallinen Seura, p. 31 .

\section{Juozas Algimantas Krikštopaitis}

Lithuanian Research Institute of Culture, Saltoniškių 8, Vilnius, Lithuania

E-mail:krikstop@ktl.mii.It 